\title{
Sad men in Beowulf
}

\section{Robin Norris}

The ink spilled defining weeping as women's work in Beowulf far exceeds the volume of their tears. We have made too much of the summary line at the opening of the Finnsburh episode declaring Hildeburh a 'geomuru ides' (sad woman) (1075b) as 'meotodsceaft bemearn' (she mourned over the decree of fate) (1077a). ${ }^{1}$ At the funeral she directs for her son and brother, 'ides gnornode, / geomrode giddum' (the woman mourned with songs) (1117-18). ${ }^{2}$ Likewise, according to her editors, a Geatish meowle sings at Beowulf's funeral (3150b). ${ }^{3}$ What can be read of the manuscript here includes 'giomorgyd' (song of mourning) (3150a) and 'sorgcearig' (sorrowful) (3152a). Indeed, these women are sad, but they are also surrounded by sad men.

Meanwhile, we have averted our tearless eyes from the mourning men who populate the poem. We may question how the Anglo-Saxons read this history of their continental ancestors, or why Christian scribes recorded it, but we do not question our own cathexis of the Anglo-Saxon hero with a stiff upper lip. Instead, we read the evidence through the lens of our own confirmation bias. As I argue in this chapter, we have made Beowulf a paragon of the heroic code without asking whose gender norms we expect him to uphold. We have done the same in our readings of the other poems we call heroic, such as The Wanderer. Early in the poem, the speaker claims:

Ic to sope wat

pæt bip in eorle indryhten peaw, pæt he his ferðlocan fæste binde, healde his hordcofan, hycge swa he wille.

Ne mæg werig mod wyrde wiðstondan, ne se hreo hyge helpe gefremman.

Forðon domgeorne dreorigne oft

in hyra breostcofan bindað fæste. $(11-18)^{4}$ 
(I know for a fact that it is a noble custom in a nobleman to bind up his spirit-locker, hold his heart-coffer, whatever he might think. A weary mind cannot withstand wyrd and a disturbed mind doesn't help. Therefore those eager for glory often bind whatever's dreary in their breast-coffer.)

But despite the nobility of this prescription, he goes on to disclose the dreary contents of his spirit-locker over the next 100 lines. In order to argue that this noble custom must have ruled the emotional lives of Anglo-Saxon men, we have cherry-picked the Wanderer's tree, blinded to the forest of his lament.

Likewise, we continue to be possessed by the Germanic spirit conjured by the Roman historian Tacitus, who famously wrote, 'Weeping and wailing they put away quickly: sorrow and sadness linger. Lamentation becomes women: men must remember', and we cling to this statement as applicable to the Anglo-Saxons, despite the fact that he was writing about continental tribes in $98 \mathrm{CE}^{5}$ Moreover, Christopher Krebs calls the Germania 'a mosaic of Greek and Roman stereotypes, arranged by a writer who most likely never went north of the Alps'; these mourning women and repressed men 'are in many ways typical representatives of the northern barbarian, sketched within the Greek and Roman ethnographical tradition by ... a Roman in Rome for Romans'. ${ }^{6}$ Not only does Tacitus present mourning as women's work, but in this same passage he notes that Germanic peoples avoid both ostentation in burial and 'the difficult and tedious tribute of a monument', an attitude that would seem to prohibit Beowulf's treasure-bedecked pyre and cliffside barrow, were he a reliable source. Tacitus also gives us the word comitatus, which is still used to encapsulate the relationship between an Anglo-Saxon leader and his thanes. ${ }^{7}$ According to the Oxford English Dictionary, the word is first attested in English in 1875 as Victorian historians thought through the roots and the nature of the English nobility. ${ }^{8}$ In the twentieth century, according to Krebs, members of the SS memorialized Tacitus's depiction of the comitatus by 'wear[ing] this German motto engraved on their [belt] buckles: Meine Ehre heißt Treue (My honour is called loyalty)'.

Medievalists have rejected the Nazi fetishization of Germanic identity, and we have begun to critique the Victorian construction of imperial Englishness, but we have left unchallenged the 'Victorian and modern views on masculinity [that] have influenced the critical reception and interpretation of male tears in the corpus of Old 
English literature', as Kristen Mills argues; 'examples of weeping men are often ignored or viewed as aberrant, while instances of women's weeping are taken as normative behaviour'. ${ }^{10}$ In response to this tendency, in the first section of this chapter I would like simply to acknowledge the many sad men who inhabit Beowulf: the catalogue below serves as a monument. Even the main characters of the poem experience sorrow - both King Hrothgar and the hero himself, as I will explain. Moreover, Beowulf also demonstrates empathy for the sorrow of others, and in the conclusion of the chapter I will discuss Beowulf's empathy and its limits, and the limits of empathy in light of the current challenges facing the field presently known as Anglo-Saxon studies.

\section{Sad men}

Beowulf is famously structured by four funerals, all conducted primarily by men. ${ }^{11}$ Clearly Hildeburh and the Geatish meowle have plenty of male company, but whereas we see these two women mourning only in a funereal context, and only in two of the four rites, we see ample evidence of male sorrow at all four funerals and throughout the poem. The men who bury the legendary hero Scyld Scefing at sea have 'geomor sefa, / murnende mod' (a sad and mourning mind) (49b-50a). ${ }^{12}$ After the funeral of Hildeburh's son and brother Hnæf, the lordless Danes are twice labelled with a compound using wea, 'woe', which Britt Mize translates as 'the trauma-remnant' ('ba wealafe') (1084a and 1098a). ${ }^{13}$ Two men named Guðlaf and Oslaf decide to kill Finn after 'sorge mændon, / ætwiton weana dæl' (speaking of their sorrow and attributing blame for their portion of woes) (1149b-50a). It is the sight of a sword that sparks this conversation, and the afterlife of arms that leads to the third funeral in Beowulf, the so-called lay of the last survivor, whom the narrator calls 'weard winegeomor' (a guardian mourning his friends) (2239). ${ }^{14}$ After he utters his twenty-line elegy (2247-66), the narrator adds:

Swa giomormod giohðo mænde an æfter eallum, unbliðe hwearf dæges ond nihtes, оð ðæt deaðes wylm hran æt heortan. (2267-70a)

(Thus one [remaining] after all [the others], sad of mind, spoke of sorrow, [then] turned joyless day and night until death's welling touched him at heart.) 
Grieving until the end of his days, the last survivor becomes a lordless wanderer, sharing the fate that befalls the Geats following Beowulf's death.

It is his funeral, the fourth and last of the poem, that is the most elaborate. It is not just the two-stage ceremony but the last five fitts of the poem that are inhabited by sad men. It was sadness that motivated Wiglaf, another 'wealaf', to help Beowulf fight the dragon, for 'weoll / sefa wið sorgum' (his mind welled with sorrows) (2599b-600a). ${ }^{15}$ Wiglaf is the only one of Beowulf's men to join him in the fight, and when he explains this decision to his companions, the narrator adds the summary line: 'him wæs sefa geomor' (his was a sad mind) (2632b). Wiglaf takes Beowulf's death 'earfoðlice' (with difficulty) (2822a), and he is 'sarigferð' (sad at heart) (2863a) when he reports the news to his companions. He sends a messenger to those awaiting the outcome, who are similarly 'modgiomor' (sad at heart) (2894b). The messenger describes Wiglaf to them as holding 'higemæðum heafodwearde' (a mind-wearying death-watch) (2909) over the bodies of the king and the dragon. He then predicts that neither nobleman nor maiden will wear treasure; instead they will experience exile, 'geomormod' (sad of mind) (3018a). ${ }^{16}$ When the messenger's work is done, the company goes 'unbliðe' (joyless) (3031a) and 'wollenteare' (with gushing tears) (3032a) to see the body.

'Lyt ænig mearn' (Little did anyone mourn) (3129b) to gather the treasure that will soon be burned and buried, but Beowulf himself is laid on the pyre by 'hæled hiofende hlaford leofne' (men lamenting their dear lord) (3142). It is 'wigend' (warriors) (3144a) who light the fire, which is 'wope bewunden' (wound about with weeping) (3146a) as 'higum unrote / modceare mændon' (the sad ones speak of soul-sorrow in their minds) (3148b-49a). Later, after they build a barrow, twelve 'hildediore, æpelinga bearn' (battle-brave children of nobles) (3169b-70a) ride around the mound. ${ }^{17}$ These men need to talk, and their words take the poem to its conclusion:

woldon care cwiðan, ond cyning mænan, wordgyd wrecan, ond ymb wer sprecan; eahtodan eorlscipe ond his ellenweorc duguðum demdon, - swa hit gedefe bið, pæt mon his winedryhten wordum herge, ferhðum freoge, bonne he forð scile of lichaman læded weorðan.

Swa begnornodon Geata leode

hlafordes hryre, heorðgeneatas. (3171-9) 
(They wished to bewail their care and speak of their king, recite a song and speak about the man; they considered his nobility and highly praised his deeds of valour - as it is fitting that a man praise his friendly lord with words, love him with their minds, when he shall be led forth from the body. Thus the people of the Geats, the hearth-companions, lamented their lord's fall.)

These twelve hearth-companions, Beowulf's battle-companions, stand in for the Geatish people as a whole as they mourn for their lord; through words, song, and praise they bewail their care and lament his fall.

What I have demonstrated here is that Beowulf is populated by sad men, though we have overlooked their emotions by focusing on the mourning of Hildeburh and the Geatish meowle. In the light of the great sorrow of the many men who participate in all four of the poem's funerals, it is clearly inaccurate to state that weeping is women's work in the poem. Nor is grief reserved for emasculated men. Beowulf himself experienced a great deal of sadness in his final days. ${ }^{18}$ The news of his hall's burning by the dragon was 'hreow on hreðre, hygesorga mæst' (sorrow in his breast, greatest of heart-sorrows) (2328). Wondering if he had offended God, his 'breost innan weoll / peostrum geponcum, swa him gepywe ne wæs' (breast within welled with dark thoughts, as was not customary for him) (2331b-2). Beowulf recalls many past obstacles overcome, but now, as his unaccustomed dark thoughts continue, we realize that he is grieving for his own imminent death, as 'him wæs geomor sefa, / wæfre ond wælfus' (his mind was sad, restless, and ready for death) (2419b-20a). After fighting the dragon, as he lies dying, when he looks on the gold, Beowulf is 'gomel on giohðe' (old in sorrow) (2793), a phrase echoed by Wiglaf when he conveys Beowulf's last wishes to the Geats ('gomol on giohðe') (3095a).

If the critical consensus will admit a mourning man to discussion of the poem, it is Hrothgar, but as Kristen Mills notes, 'It is a commonplace of Beowulf-scholarship to observe that Hrothgar serves as a foil to Beowulf, and thus one's interpretation of Hrothgar's behaviour will depend largely on how one views Beowulf., ${ }^{19}$ If Beowulf is the paragon of heroic masculinity, then Hrothgar must pale by comparison. But if Beowulf is a man who experiences sorrow himself, then we must re-evaluate our reading of Hrothgar. First, we must understand that the sorrow of the Danish people becomes the context for Hrothgar's own sadness. When the Danes learn of Grendel's first attack, which takes the lives of thirty thanes, 
they respond with 'wop' (weeping) (128b), 'micel morgensweg' (a great morning sound [of wailing]) (129a). The king sits 'unbliðe' (joyless) (130b), ‘bolode ðryðswyð, pegnsorge dreah’ (suffering and enduring strong sorrow for thanes) (131). Thus begins twelve years of suffering for Hrothgar: 'Wæs seo hwil micel: / twelf wintra tid torn gepolode / wine Scyldinga, weana gehwelcne, / sidra sorga' (It was a long time: for twelve winters, the friend of the Danes suffered grief, each woe of great sorrows) (146b-9a). Word begins to spread through 'gyddum geomore' (sad songs) (151a) about Grendel's conflict with Hrothgar, so that even Hygelac, king across the sea, later refers to Hrothgar's 'widcuðne wean' (widely known woe) (1991a). Yet the narrator continues to emphasize Hrothgar's sorrow: 'Pæt wæs wræc micel wine Scyldinga, / modes brecða' ('That was great misery and heartbreak [lit. breaking of mind] for the friend of the Danes) (170-1a). And there is one last description of Hrothgar's emotional state before the narrator introduces Beowulf: 'Swa ða mælceare maga Healfdenes / singala seað; ne mihte snotor hæleð / wean onwendan' (So the son of Healfdene was agitated by continual cares; nor could the prudent man turn aside woe) (189-91a).

When Beowulf arrives, then, he touts the benefit of his services as not merely logistical but therapeutic, since he will cause Hrothgar's 'cearwylmas colran wurðap' (seething sorrows to become cooler) (282). When Hrothgar replies to this offer, he admits, 'Sorh is me to secganne on sefan minum / gumena ængum hwæt me Grendel hafað / hynðo on Heorote mid his hetepancum, / færniða gefremed' (It is a sorrow in my mind for me to say to anyone what Grendel has done to me in Heorot, humiliation and hostile attacks, with his thoughts of hate) (473-6). After Grendel's death, Hrothgar reemphasizes that he had endured 'grynna æt Grendle' (grief from Grendel) (930a) without ever expecting relief from any 'weana' (woe) (933a), but relief came in the person of Beowulf, as advertised. ${ }^{20}$ Thus, when Grendel's mother arrives, 'cearu wæs geniwod' (care was renewed) (1303b). This sentiment is repeated when Hrothgar explains to Beowulf that \#schere has died: 'Sorh is geniwod / Denigea leodum' (Sorrow is renewed for the people of the Danes) (1322b-3a). And when they find Æschere's head, 'Denum eallum wæs, / ... weorce on mode / to gepolianne' (it was painful in mind for all Danes to suffer) (1417b-19a).

How does Hrothgar himself respond to Æschere's death? The narrator tells us that he is 'on hreon mode' (in a troubled frame of mind) (1307b) and worries that God will never end his 'weaspelle' 
(news of woe) (1315a). Yet when Hrothgar speaks of Eschere to Beowulf, he begins with praise for his retainer, and ends with the information Beowulf needs to find and kill Grendel's mother. Hrothgar concludes this speech by promising Beowulf payment for the feud (1380-2) - in other words by hiring Beowulf to exact revenge. According to Erin Sebo, 'Hrothgar's mind is bent solely on revenge and he gives Beowulf as much information as he can to assist with the tracking and killing of Grendel's mother.' ${ }^{21}$ It is in this context that Beowulf gives his famous reply: 'Ne sorga, snotor guma. Selre bið æghwæm / pæt he his freond wrece ponne he fela murne' (Do not sorrow, wise man. It is better for anyone to avenge his friend than to mourn much) (1384b-5), and he concludes, 'Đys dogor bu gepyld hafa / weana gehwylces, swa ic be wene to' (Today have patience for every woe, as I expect you to) (1395-6), after which Hrothgar leaps up and rides off. But a myopic focus on Beowulf's words as evidence of the heroic code has led us too often to extrapolate a total ban on mourning. Moreover, reading Beowulf and Hrothgar in juxtaposition has led us to assume that revenge is Beowulf's idea because Hrothgar has been mourning too much, when both of these conclusions are disproven by the textual evidence.

Likewise, the parting of Beowulf and Hrothgar is one of the most poignant episodes in the poem, but it is more often read as evidence of Hrothgar's failing masculinity. ${ }^{22}$ Bearing in mind the fact that Hrothgar has been in constant mourning for the past twelve years, he actually copes fairly well with Beowulf's departure. In her reading of this scene, Leslie Lockett argues that Hrothgar succeeds in keeping 'his intense sadness' internalized, ${ }^{23}$ as if he has flexed his mind-tethers 'to keep words and tears from escaping from the breast, but at the risk of increasing the heat and pressure inside the chest cavity'. ${ }^{24}$ Since Hrothgar does apparently shed tears, Kristen Mills 're-examine[s] the farewell scene in light of other texts where the formula of a man falling on another's neck, kissing him, and weeping occurs' ${ }^{25}$ these parallels do not suggest 'abnormality or effeminacy when men embrace, kiss, and weep during a reunion'. ${ }^{26}$

This farewell is not a definitive moment of closure but leaves many questions open: Whose tears are falling and why? Do the two men expect to meet again? Will they? But we cannot yield to the mystery of poetry if we assume that we already know all the answers. The goodbye appears on folios $173 \mathrm{v}-174 \mathrm{r}$ of the manuscript. It is Beowulf's request to leave, to return to his own king, that sets the 
stage for this scene, which the narrator depicts entirely from Hrothgar's perspective:

Het hine mid pæm lacum leode swæse secean on gesyntum, snude eft cuman.

Gecyste ba cyning æelum god, peoden Scyldinga ðegn betestan

ond be healse genam; hruron him tearas

blondenfeaxum. Him wæs bega wen, ealdum infrodum opres swiðor, pæt hie seoððan [no] geseon moston, modige on meple. Wæs him se man to pon leof pæt he pone breostwylm forberan ne mehte; ac him on hrepre hygebendum fæst æfter deorum men dyrne langað beorn wið blode. (1868-80a)

(Hrothgar commanded him to go home to his people safely with these gifts, and come again soon. Then the king of good stock, the lord of the Danes, kissed the best of thanes and took him by the neck; tears fell [from/onto] him, the greying one. For the wise old man, there was expectation of two outcomes, one more likely than the other, that they would [not?] see each other afterward, emotional about meeting. The man was so dear to him that he could not forbear the breast-welling, but in his heart, firmly bound in his mind, an unspoken longing for the dear man burned in his blood.)

When Hrothgar takes Beowulf by the neck, Beowulf apparently consents, accepting if not reciprocating the embrace, and he may even kneel before the king, as does the speaker in The Wanderer. ${ }^{27}$ If this is the case, then tears may well have fallen onto him from the greying one. If Beowulf is standing, however, assuming that Beowulf is taller, more erect in posture, or less stooped by age, we must consider the possibility that his tears may have fallen onto the greying one. What is clear is that Hrothgar has embraced Beowulf, and that one man touches another with that most taboo of bodily fluids, manly tears, whether a head lies on a shoulder or knee, or a face is buried in a chest. Hrothgar grants Beowulf's request to leave with a command to do so, but the het construction also allows Hrothgar to add his own wish that Beowulf should come again soon. Whether or not this will happen seems to be the crux of the episode.

Notice that halfway through the passage, due to damage to the top right corner of $174 \mathrm{r}$, the editors have added a final $-n$ to seoððan as well as the word no in line $1875 .^{28}$ The editors' note to this line 
begins: 'The text yields more transparent sense with the assumption of a lost negative adverb.' 29 'After seoðða', they go on to explain, 'Thorkelin's amanuensis leaves a lengthy space, implying the loss of more than a single n.' 'The editors also attempt an argument on the basis of metrical parallels 'in the formally most regular poems'. But both of these pieces of evidence are adduced in the interest of 'more transparent sense'. The editorial addition of no indicates that Hrothgar does not think he will ever see Beowulf again, which is the scenario modern readers associate with a tearful goodbye, and therefore yields 'more transparent sense' to the editors. Without no, however, we can assume that Hrothgar is in fact imagining a future reunion with Beowulf, which may explain why Mills has found tearful parallels in scenes of reunion. In fact, if a reunion calls for tears in Old English literature, it could be that Hrothgar is imagining this future scene of the two men 'modige on meple' (emotional at meeting). This, then, would be the cause of Hrothgar's irrepressible 'boiling in the breast', as Lockett translates it, ${ }^{31}$ but she also points out that Hrothgar's longing for his dear one remains unspoken, burning in his blood, firmly rooted in his 'mind-tethers'. ${ }^{32}$

\section{Beowulf's empathy}

What is going through Beowulf's mind at this point we do not know, but I would argue that he receives Hrothgar with empathy, as evinced by his first-person account of his journey once he returns home. His audience is yet another sad king, Hygelac, who greets him with claims of worry for the journey: 'Ic ðæs modceare / sorhwylmum seað' (I seethed with sorrow of soul and surging sorrows) (1992b-3a). As he begins to explain all that has occurred, Beowulf describes Grendel's work in the hall 'bær he worna fela / Sige-Scyldingum sorge gefremede, / yrmðe to aldre' (where he always caused the Danes so much sorrow and misery) (2003b-5a) with empathy for Hrothgar and his people. In particular, he notes that the loss of Æschere was the 'hreowa tornost' (cruellest of sorrows) (2129b) for Hrothgar, leaving him 'hreohmod' (troubled in mind) (2132a). In a seeming digression, Beowulf introduces Hrothgar's daughter Freawaru to the poem, empathetically imagining the precarious situation she is being married into as a peace-weaver, in parallel to Hildeburh's fate. He predicts that an old spearbearer, 'geomormod' (sad of mind) (2044a), with 'grim sefa' (a grim mind) (2043b), will incite revenge just as Guðlaf and Oslaf did. Unique among the humans in the poem, Beowulf's empathy extends even 
to the Grendelkin. It is only Beowulf who, in recounting his exploits, notes that Grendel left the hall 'modes geomor' (sad in mind) (2100a) after their fight. In fact, the narrator notes that Grendel's death did not seem 'sarlic' (painful) (842a) to them. ${ }^{33}$ As for Grendel's mother, the narrator refers to her 'sorhfulne sið, sunu deoð wrecan' (sorrowful trip to avenge her son's death) (1278), and Beowulf echoes this in his retelling, stating that she 'siðode sorhfull' (travelled sorrowful) (2119a) to seek revenge. ${ }^{34}$ If Beowulf can empathize with Freawaru's hypothetical sorrow and even monstrous sorrow, I have no doubt that he responded to Hrothgar with empathy in the flesh. But when faced with mourning men in Old English literature, scholars have not generally acknowledged evidence of their thoughts and feelings, nor responded with sensitivity and care to their suffering.

Despite a recent boom in empathy scholarship, even experts in the field acknowledge the term's short history and contested or multivalent meanings. ${ }^{35}$ The word first appears in English as a borrowing from German around the turn of the twentieth century, but its current meaning is attested in 1946, and this definition was only added to the OED in $2014 .{ }^{36}$ Nonetheless, the experience of empathy is a human one, rather than a recent development, as Antonina Harbus explains:

Our understanding and empathy with the emotional complexity of the subjective experience represented in the [Old English] text [here, Wulf and Eadwacer] are predicated on comparable human psychological functioning shared by the creator and receiver of this text. Moreover, the apparent cross-cultural intelligibility of the text and its emotional texture points to consistency rather than variation in human apprehension of and cause for emotional pain, as well as the deep entrenchment of the reliance on poetry to represent and to engage with the emotional life. ${ }^{37}$

Thus, 1,000 years later, we can empathize with characters in medieval literature. But what is empathy? Richard Delgado defines it as 'the capacity to project or imagine the thoughts and feelings of another person' ${ }^{38}$ C. Daniel Batson explains that the term is used to refer to at least eight separate phenomena, but he synthesizes these into two aspects of empathy: knowing the internal state of another (i.e., their thoughts and feelings), and responding with sensitivity and care to their suffering. ${ }^{39}$ Using these two criteria, we can also recognize when medieval figures such as Beowulf exhibit empathy themselves. 
Harbus comments above on 'the reliance on poetry to represent and to engage with the emotional life'. Likewise, Britt Mize argues for a connection between literature and mentality for the AngloSaxons. 'Much Old English poetry is straightforwardly about mental states', he writes, 'but even that which is not in the ordinary sense "about" mentality still, somehow, is, returning insistently to qualities, conditions, and actions of the mind. ${ }^{40}$ In 2013 David Comer Kidd and Emanuele Castano argued that reading literary fiction fosters Theory of Mind in adults, and their findings were popularly reported as if reading literature increases empathy, though the study was later critiqued by other psychologists. ${ }^{41}$ To the extent that fiction does foster empathy, it is worth wondering whether the digressions in Beowulf perform a similar function. After all, one of the most tragic scenes in the poem, the Finnsburh episode, is one such digression, and it must be one of the 'gyd ... so ond sarlic' (true and painful songs) (2008-9) told at Heorot, as Beowulf recounts.

Beowulf himself gives voice to a digression within a digression when he describes the experience of a hanged man's father in the midst of his account of King Hrethel's sorrow. As Beowulf processes his dark thoughts and prepares for own death, he searches for parallels to understand his own situation and finds them in the experiences of other mourning men. First, he recalls the death of Herebeald at the hands of his brother, and its impact on their father King Hrethel, by whom Beowulf was fostered at the age of seven (2435-43 and 2462-71). This incident was 'hreðre hygemeðe' (mind-wearying to the heart) (2442a), and Hrethel 'heortan sorge / weallinde wæg' (carried welling sorrow in his heart) (2463b-4a) until it killed him. In Beowulf's own words, 'He ða mid pære sorhge, pe him sio sar belamp, / gumdream ofgeaf, Godes leoht geceas' (Then with the sorrow, the pain that befell him, he gave up the pleasures of men, chose God's light) (2468-9). Here Beowulf seems to confess that he too has chosen death in the midst of an untenable situation, but in the process he is showing empathy for the sadness of another king who was dear to him.

Within his account of this historical precedent, Beowulf introduces a hypothetical or fictional scenario featuring another mourning man: the father of a young man sentenced to hang (2444-62). This experience is 'geomorlic' (sad) (2444a) for the old man. When his son hangs, 'he gyd wrece, / sarigne sang' (he recites a sad song) (2446b-7a), not unlike Hildeburh did. Every morning he remembers his son's passing (2450). Then Beowulf offers an elegiac moment of his own creation that begins: 'Gesyhð sorhcearig on his suna 
bure / winsele westne, windge reste, / reotge berofene' (Sorrowful, in his son's empty chamber, he envisions the deserted hall and the windswept resting place, dreary, emptied) (2455-7a). Neither this man nor King Hrethel can avenge his son's death, and both are haunted by the loss until they choose death, for Hrethel chooses God's light (2469) and the hanged man's father takes to his bed: 'Gewiteð ponne on sealman, sorhleoð gæleð / an æfter anum; puhte him eall to rum, / wongas ond wicstede' ('Then he goes to his bed, sings one song of sorrow after another; the residence and the plains seem all too roomy to him) (2460-2a). ${ }^{42}$ Since Beowulf has no son, it must not be the specifics of the situation but these emotions of helplessness and loss with which he empathizes.

\section{The limits of empathy}

Throughout this chapter, I have demonstrated that Beowulf is populated by mourning men, including the hero himself, who is in fact an exemplar of empathy towards the feelings of his fellow warriors. Why then does Beowulf seem oblivious to the fate of the Geatish people? With his death, the prophecy of the Geatish meowle is 'heregeongas ... wælfylla worn, werudes egesan, / hynðo ond hæftnyd' (invasions, many slaughters, the terror of the troop, humiliation and captivity) (3153-5a). In denial of this reality, Beowulf consoles himself with the gold he leaves behind. One of his last wishes is to see the treasure so that he can die 'ðy seft' (more easily) (2749b). He gives thanks to God for the hoard he acquired 'for his people' (minum leodum) (2797b) and explains: 'Nu ic on maðma hord mine bebohte / frode feorhlege, fremmað gena / leoda pearfe' (Now that I have sold my old lifespan for this hoard of treasures, they will attend to the needs of the people) (2799-801a). ${ }^{43}$ But gold is not what his people really need; they need a living lord to defend them.

Rather than putting his people first by truly understanding their experience, Beowulf imagines what he, a noble lord, would need in this situation: namely, the wealth that enables his power in life, and failing that, the glory enabled by death. This is false empathy, for he has made the mistake of thinking that he knows what his people want. ${ }^{44}$ Delgado's work on empathy, false empathy, and the empathic fallacy is fundamental to Critical Race Theory, and helps to elucidate the emotional crux that is the end of the poem. ${ }^{45}$ To paraphrase Delgado, Beowulf has postulated a recipient who will like and appreciate what he would have wanted had he been in exactly 
that situation. ${ }^{46}$ As a good lord, he is nonetheless 'beyond reproach', ${ }^{47}$ and the poem itself becomes a vehicle of both his self-image and the hierarchical society that enables it. The poem, therefore, asks us to empathize with Beowulf's needs, rather than those of the Geats, who are denied the 'full due process of storytelling'. ${ }^{48}$

Beowulf's emotional life therefore offers two important lessons for early medievalists. First, the sorrow of both the hero and the other men of the poem, as well as the empathy Beowulf expresses for his fellow warriors, remind us that gender is culturally constructed, and that we must become aware of the filter of our own post-modern experience in order to see medieval literature on its own terms. Second, though it is based on class rather than race, Beowulf's false empathy for the Geatish people is an object lesson that is fundamental to Critical Race Theory. As Delgado explains:

$[\mathrm{F}]$ alse empathy is worse than none at all, worse than indifference. It makes you over-confident, so that you can easily harm the intended beneficiary. You are apt to be paternalistic, thinking you know what the other really wants or needs. You can easily substitute your own goal for hers. You visualize what you would want if you were she, when your experiences are radically different, and your needs, too. ${ }^{49}$

Because 'the real kind, true empathy, is in extremely rare supply', 50 Delgado ultimately concludes by forswearing empathy altogether, arguing instead for white allyship in dismantling white supremacy. Meanwhile, when white early medievalists such as me find ourselves in sympathy with our non-white colleagues, we can question whether our empathy is false or true, and ask ourselves whether we are showing respect for the established scholarly discourse on race, citing minority voices, and - most importantly - listening to medievalists of colour, as we have been asked to do. ${ }^{51}$

\section{Notes}

1 The Finnsburh episode is one of the most famous digressions in Beowulf; the narrator recounts how the scop tells this story for entertainment in the hall. Hildeburh is a 'peace-weaver', a woman married off in an attempt to cement an alliance between tribes. She loses her son and brother in the same battle, and then loses her husband when they are avenged by her people. For further discussion, see below and Mary Kate Hurley's chapter in this volume, pp. 147-63. For consistency, I lean on R. D. Fulk, Robert E. Bjork, and John D. Niles's glossary in Klaeber's Beowulf, 4th edn (Toronto: University of Toronto Press, 2008), translating the short phrases in the first section of this chapter. 
All citations to Beowulf are by line number from this edition, hereafter referred to as Klaeber 4.

2 What I object to is fetishization of Hildeburh in the service of creating a through-line from Tacitus to the Victorians to the present day, allowing us to ignore men's sadness by overemphasizing women's sorrow. The figure of the mourning woman became the focus of important feminist criticism such as Joyce Hill's 'Pæt wæs geomuru ides! A female stereotype examined', in Helen Damico and Alexandra Hennessy Olsen (eds), New readings on women in Old English literature (Bloomington, IN: Indiana University Press, 1990), pp. 235-47. See also Stacy S. Klein, Ruling women: queenship and gender in Anglo-Saxon literature (Notre Dame, IN: University of Notre Dame Press, 2006). Klein notes the presence of mourning women in other poems such as Deor and The Fortunes of Men (p. 99). She argues that the grief of Hildeburh allows readers to question and critique the heroic code, a reaction that helps to inaugurate a new, internal form of heroism, which preserves a space for the emotional lives of men.

3 See Helen Bennett, 'The female mourner at Beowulf's funeral: filling in the blanks/hearing the spaces', Exemplaria, 4.1 (1992), 35-50; Tauno F. Mustanoja, 'The unnamed woman's song of mourning over Beowulf and the tradition of ritual lamentation', Neuphilologische Mitteilungen, 68 (1967), 1-27.

4 The Wanderer, ed. G. P. Krapp and E. V. K. Dobbie, The Exeter Book, ASPR 3 (New York: Columbia University Press, 1936), pp. 134-7.

5 Tacitus, Germania, Loeb Classical Library 35, www.loebclassics.com/ view/tacitus-germania/1914/pb_LCL035.171.xml (accessed 5 June 2019). Here is the full passage and its translation at pp. 170-1: 'Funerum nulla ambitio: id solum observatur, ut corpora clarorum virorum certis lignis crementur. struem rogi nec vestibus nec odoribus cumulant: sua cuique arma, quorundam igni et equus adicitur. sepulcrum caespes erigit: monumentorum arduum et operosum honorem ut gravem defunctis aspernantur. lamenta ac lacrimas cito, dolorem et tristitiam tarde ponunt. feminis lugere honestum est, viris meminisse.' ('In burial there is no ostentation: the single observance is to burn the bodies of their notables with special kinds of wood. They build a pyre, but do not load it with palls or spices: to each man his armour; to the fire of some his horse also is added. The tomb is a mound of turf: the difficult and tedious tribute of a monument they reject as too heavy on the dead. Weeping and wailing they put away quickly: sorrow and sadness linger. Lamentation becomes women: men must remember.').

6 Christopher B. Krebs, A most dangerous book: Tacitus's Germania from the Roman Empire to the Third Reich (New York: Norton, 2011), p. 49. See also Loretana de Libero, 'Precibus ac lacrimis: tears in Roman historiographers', in Thorsten Fögen (ed.), Tears in the Graeco-Roman world (Berlin and New York: De Gruyter, 2009), pp. 209-34.

7 See Tacitus, Germania, pp. 150, 152. 
8 Oxford English Dictionary, s.v. comitatus.

9 Krebs, A most dangerous book, pp. 46, 238.

10 Kristen Mills, 'Emotion and gesture in Hroðgar's farewell to Beowulf', in Alice Jorgensen, Frances McCormack, and Jonathan Wilcox (eds), Anglo-Saxon emotions: reading the heart in Old English language, literature and culture (Farnham: Ashgate, 2015), pp. 163-75, at 166.

11 Gale R. Owen-Crocker, The four funerals in Beowulf (Manchester: Manchester University Press, 2009).

12 Scyld himself awaited consolation for his destitute origins ('ærest wearð / feasceaft funden. He pæs frofre gebad') (6b-7), not a happy position to be in.

13 See Britt Mize's discussion of the term in Traditional subjectivities: the Old English poetics of mentality (Toronto: University of Toronto Press, 2013), pp. 175-81. Klaeber 4 gives 'survivors of calamity'.

14 The last survivor voices his lament while burying the treasure of his now-extinct people in the barrow that will become the dragon's lair. The mound is later discovered by a runaway slave, who steals a golden cup in the hope of appeasing his lord, inadvertently waking the dragon and inciting its attacks. When forced to reveal the barrow, the slave is sad in mind as he leads Beowulf and his men there (2408).

15 Leslie Lockett explains the importance of welling and seething in the Anglo-Saxons' hydraulic model of the mind, our understanding of which can be distorted by a focus on mind-body dualism. See Anglo-Saxon psychologies in the vernacular and Latin traditions (Toronto: University of Toronto Press, 2011).

16 These dozen lines (3015-27) become an elegy for the exiled Geats that recalls the words of the last survivor.

17 These bearn are not minors but noblemen. The phrase is used in reference to the Danes and Geats who go to look for Æschere's body (1408) and to describe the comrades who abandoned Beowulf to the dragon (2597). The repetition of this phrase with the adjective 'battle-brave' must be deliberate and ironic.

18 Perhaps we can include his return to Geatland as an 'earm anhaga' (wretched solitary being) (2368a) after he heard the news of Hygelac's death.

19 Mills, 'Emotion and gesture', p. 164.

20 Similarly, after Grendel's mother is dead, Hrothgar reflects on the 'gyrn æfter gomene' (grief after joy) (1775) that Grendel had brought and 'modceare micel' (great sorrow of soul) (1778) that he suffered as a result. In other words, every time Beowulf delivers on the cessation of sorrow he has promised, Hrothgar remembers the twelve long years that have just come to an end.

21 Erin Sebo offers a cogent reading of this scene in ' $N e$ sorga: grief and revenge in Beowulf', in Jorgensen, McCormack, and Wilcox (eds), Anglo-Saxon emotions, pp. 177-92, at 180. See also her discussion of the overemphasis on vengeance in the scholarly tradition at pp. 177-8. 
22 See T. Wright, 'Hrothgar's tears', Modern philology, 65 (1967), 39-44; and Mary Dockray-Miller, 'Beowulf's tears of fatherhood', Exemplaria, 10 (1998), 1-28. A more nuanced reading of Hrothgar appears in Klein's Chapter 3: 'Beowulf and the gendering of heroism' in Ruling women.

23 Lockett, Anglo-Saxon psychologies, pp. 82-3.

24 Ibid., p. 83.

25 Mills, 'Emotion and gesture', p. 165.

26 Ibid., p. 172. Moreover, in the hagiographic tradition that was no doubt familiar to the scribes of Beowulf, the generic conventions of the uita require a saint's followers to mourn upon their farewell; this includes Andreas, Guthlac, Martin, and even Christ. At the same time, we have not attended to the negative attitude towards sorrow exemplified by Ælfric and other Christian writers. Thus, the situation is far more complicated than our oversimplifications admit. See, for example, my 'Reversal of fortune, response, and reward in the Old English Passion of Saint Eustace', in Robin Norris (ed.), Anonymous interpolations in AElfric's Lives of Saints (Kalamazoo, MI: Medieval Institute Publications, 2011), pp. 97-117.

27 The sleeping Wanderer dreams that 'he his mondryhten / clyppe ond cysse, ond on cneo lecge / honda ond heafod' (he embraced and kissed his lord, and laid hands and head on his knee) (41b-3a). The narrator states that in reality, the Wanderer did this 'hwilum ær in geardagum' (sometimes before in the old days) (43-4), so the dream may be a memory of the past, a present experience imagined by the dreamer, or a desired future reunion.

28 Cf. wees, breost, and on supplied at the ends the next three lines in the manuscript.

29 Klaeber 4, p. 220.

30 Ibid.

31 Lockett, Anglo-Saxon psychologies, p. 83.

32 Ibid., p. 82.

33 On Grendel's monstrous lack of empathy, see Antonina Harbus, Cognitive approaches to Old English poetry (Cambridge: Cambridge University Press, 2012), pp. 126-9.

34 Unferth calls the swimming contest with Breca 'sorhfullne sið' (sorrowful journey) (512), and sea monsters can turn a voyage into 'sorhfulne sið' (1429a).

35 Jean Decety and William Ickes (eds), The social neuroscience of empathy (Cambridge, MA: MIT Press, 2009), p. vii.

36 Def. 2b: 'The ability to understand and appreciate another person's feelings, experience, etc.'

37 Harbus, Cognitive approaches, pp. 172-3. See also her 'Affective poetics: the cognitive basis of emotion in Old English poetry', in Jorgensen, McCormack, and Wilcox (eds), Anglo-Saxon emotions, pp. 19-34.

38 Richard Delgado, 'Rodrigo's eleventh chronicle: empathy and false empathy', California law review, 84.1 (1996), 61-100, at 68 n. 25. 
39 C. Daniel Batson, 'These things called empathy: eight related but distinct phenomena', in Decety and Ickes (eds), The social neuroscience of empathy, pp. 3-15. This essay comprises the book's first section, entitled 'What is empathy?'

40 Mize, Traditional subjectivities, p. 9.

41 David Comer Kidd and Emanuele Castano, 'Reading literary fiction improves Theory of Mind', Science, 342 (2013), 377-80; M. E. Panero et al., 'Does reading a single passage of literary fiction really improve Theory of Mind? An attempt at replication', Fournal of personality and social psychology, 111.5 (2016), e46-e54.

42 Carol Clover calls his lament 'precisely the effect of disabled masculinity', but since Beowulf, the paragon of heroic masculinity, invents and invokes this sad man as a parallel to his own sad situation, and since this father's experience of grief until death seems similar to that of King Hrethel and the last survivor, I disagree. See Clover, 'Regardless of sex: men, women, and power in early Northern Europe', Speculum, 68 (1993), 363-88, at 383 n. 68.

43 This is the translation by R. M. Liuzza, who notes that the verb is 'unambiguously plural'. See Beowulf: a new verse translation, 2nd edn (Peterborough, Ont.: Broadview Press, 2000).

44 See Delgado, 'Rodrigo's eleventh chronicle', $70 \mathrm{ff}$.

45 See, for example, Richard Delgado and Jean Stefancic, Critical Race Theory: an introduction (New York: New York University Press, 2012), especially 'The empathic fallacy', pp. 27-9.

46 Delgado, 'Rodrigo's eleventh chronicle', 74.

47 Ibid., 78.

48 Ibid., 85.

49 Ibid., 94.

50 Ibid., 73.

51 See, for example, the comments by Jonathan Hsy and the bibliography on race and medieval studies at http://www.inthemedievalmiddle.com/2017/06/ morevoices-citation-inclusion-and.html (accessed 5 June 2019). The Medievalists of Color website is http://medievalistsofcolor.com. My thanks to Eileen Joy, Dana Oswald, Mary Rambaran-Olm, and the editors for their comments on a draft of this chapter. I am solely responsible for any remaining errors and infelicities. 